\title{
Progress and Challenges in the Search for the Mechanisms of Pulsatile Gonadotropin-Releasing Hormone Secretion
}

\author{
Stephanie Constantin* \\ Cellular and Developmental Neurobiology Section, National Institute of Neurological Disorders and Stroke, National Institutes \\ of Health, Bethesda, MD, United States
}

\section{OPEN ACCESS}

Edited by:

Alfonso Abizaid,

Carleton University, Canada

Reviewed by:

Daniel J. Spergel,

Yale University, United States

Zvi Naor,

Tel Aviv University, Israel

*Correspondence:

Stephanie Constantin constantinss@mail.nih.gov

Specialty section: This article was submitted to Neuroendocrine Science, a section of the journal Frontiers in Endocrinology

Received: 07 June 2017 Accepted: 10 July 2017

Published: 24 July 2017

Citation:

Constantin S (2017) Progress and Challenges in the Search for the

Mechanisms of Pulsatile

Gonadotropin-Releasing

Hormone Secretion.

Front. Endocrinol. 8:180.

doi: 10.3389/fendo.2017.00180
Fertility relies on the proper functioning of the hypothalamic-pituitary-gonadal axis. The hormonal cascade begins with hypothalamic neurons secreting gonadotropinreleasing hormone $(\mathrm{GnRH})$ into the hypophyseal portal system. In turn, the $\mathrm{GnRH}$ activated gonadotrophs in the anterior pituitary release gonadotropins, which then act on the gonads to regulate gametogenesis and sex steroidogenesis. Finally, sex steroids close this axis by feeding back to the hypothalamus. Despite this seeming straightforwardness, the axis is orchestrated by a complex neuronal network in the central nervous system. For reproductive success, GnRH neurons, the final output of this network, must integrate and translate a wide range of cues, both environmental and physiological, to the gonadotrophs via pulsatile $\mathrm{GnRH}$ secretion. This secretory profile is critical for gonadotropic function, yet the mechanisms underlying these pulses remain unknown. Literature supports both intrinsically and extrinsically driven GnRH neuronal activity. However, the caveat of the techniques supporting either one of the two hypotheses is the gap between events recorded at a single-cell level and GnRH secretion measured at the population level. This review aims to compile data about $\mathrm{GnRH}$ neuronal activity focusing on the physiological output, $\mathrm{GnRH}$ secretion.

Keywords: gonadotropin-releasing hormone release, preovulatory surge, gonadotropin-releasing hormone pulsatility, kisspeptin, electrophysiology, calcium imaging

\section{INTRODUCTION}

Fertility and its onset, puberty, are integrated phenomena. A complex network in the central nervous system (CNS), conveying physiological and environmental signals, converges onto neurons secreting gonadotropin-releasing hormone ( $\mathrm{GnRH})$. GnRH leads the hormonal cascade, driving gonadotrophs to secrete gonadotropins, which in turn control the gonads, i.e., steroidogenesis and gametogenesis in both sexes and ovulation in females. Thus, GnRH neurons are the output of the CNS for fertility, integrating and encoding cues into a signal readable by gonadotrophs, GnRH. However, GnRH neurons are not an on/off switch but a precise rheostat. GnRH secretion is pulsatile, with changes in amplitude and frequency over time. Yet, the mechanisms by which GnRH neurons generate pulses are unknown. This review summarizes recent data about GnRH neurons with a focus on secretion and the difficulty of answering this fundamental question. 
Undoubtedly, cells upstream of $\mathrm{GnRH}$ neurons contribute to fertility by helping to provide the homeostatic conditions necessary for survival. However, in this review, the word fertility simply refers to the ability to generate gametes and offspring in optimal breeding conditions.

\section{NEUROANATOMICAL DISTRIBUTION OF GnRH CELL BODIES}

Gonadotropin-releasing hormone neurons derive from the olfactory placodes $(1,2)$ and migrate into the hypothalamus during prenatal development [reviewed in Ref. $(3,4)]$. GnRH processes then extend toward the median eminence (ME) (5). This embryonic feature shapes the GnRH neuronal distribution (6). In mouse and rat, the distribution, centered around the preoptic area (POA) and the organum vasculosum laminae terminalis (OVLT), respectively $(7,8)$, is largely confined to the rostral forebrain. In monkey, it expands caudally to the mediobasal hypothalamus $(\mathrm{MBH})(9,10)$. However, data suggest that the location of the cell bodies is not important to trigger luteinizing hormone (LH) and promote fertility, as long as GnRH nerve terminals reach the hypophyseal portal system. In hypogonadal mice bearing a deletion in the $G n R H$ gene (11), transplantation of fetal POA in the rostral third ventricle restores spermatogenesis (12) and pregnancies (13). Similarly, in female monkeys with lesioned $\mathrm{MBH}$, menstrual cycles are restored with transplantation of olfactory placodes in the third ventricle (14). Notably, the pregnancies in mice receiving transplants are initiated by reflex, not spontaneous, ovulation (15), but still indicate gametogenesis and an ovulatory surge occur (16). Two possibilities, extrinsic to GnRH neurons, might explain the absence of spontaneous ovulation in transplanted mice: the required inputs (1) cannot reach transplanted GnRH neurons in their abnormal location and/or (2) are reduced/absent in hypogonadal mice (17). In contrast, in female monkeys, cyclicity was recovered since the inputs were present, i.e., the hypothalamic-pituitary-gonadal (HPG) axis was functional before its disruption. The next section addresses the distinct mechanisms for $\mathrm{GnRH}$ secretion leading to ovulation and gametogenesis.

\section{GnRH SECRETION AND FERTILITY}

Gonadotropin-releasing hormone neurons have two modes of secretion: surge triggering ovulation, restricted to females, and pulses regulating gametogenesis and sex steroidogenesis, in both sexes. In rat, $90 \%$ of $\mathrm{GnRH}$ neurons project outside the bloodbrain barrier as indicated by Fluorogold retrograde labeling (18). In mouse, only $64 \%$ of GnRH neurons are labeled in intact animals but hormonal manipulation labels $88 \%$ (19). Unfortunately, peripheral injection of Fluorogold does not discriminate the uptake site. In addition to the ME (20), GnRH neurons exhibit branched processes beyond the blood-brain barrier into the OVLT (21). Thus, the hypophysiotropic proportion of the GnRH population is unknown. Lectin wheat germ agglutinin applied onto the ME reveals an uptake in up to $59 \%$ of $\mathrm{GnRH}$ neurons (22). While the majority of GnRH neurons probably connect to the ME, a specific number might be irrelevant since few $\mathrm{GnRH}$ neurons are needed to acquire and maintain fertility $(12,13,23)$. Some GnRH neurons may project to other brain areas, in addition to or instead of the ME and OVLT, and may control additional functions $(24,25)$.

\section{Puberty}

Puberty is the developmental time an organism acquires its reproductive capacity. Physiologically, puberty coincides with activation of the HPG axis [reviewed in Ref. $(26,27)$ ]. Although this review is not about puberty, I introduce kisspeptinexpressing neurons here (28-30), since puberty onset requires direct contacts onto GnRH neurons, via kisspeptin receptor (GPR54) (31).

Kisspeptin neurons are localized in two hypothalamic areas: rostral periventricular area of the third ventricle (RP3V) and the arcuate nucleus (ARC). Both subpopulations express the estrogen receptor alpha and the expression of Kiss1 gene is sensitive to circulating sex steroids $(32,33)$. GnRH neurons do not express estrogen receptor alpha $(34,35)$ and cannot directly integrate gonadal steroid feedback (36). Hence, the role of kisspeptin neurons goes beyond puberty, contributing to fertility throughout life (37). Estradiol has opposite effects on kiss 1 gene expression in the $\mathrm{RP} 3 \mathrm{~V}$ and ARC in rodents $(32,33)$. This divergence serves the two GnRH secretory modes. Although the anatomical and functional segregation of the two kisspeptin subpopulations is not obvious in other species (38), rodents help decipher the mechanisms for surge and pulses.

\section{Preovulatory GnRH Surge}

The neurobiology of the preovulatory GnRH surge is reviewed in detail $(39,40)$. Only a subset of GnRH neurons generates the abrupt release of $\mathrm{GnRH}$ into the hypophyseal portal system. In rodents, activated $\mathrm{GnRH}$ neurons are immunocytochemically identified by immediate early genes $(41,42)$. In rat and mouse, $\sim 40 \%$ of GnRH neurons, express cFos at the time of the surge $(41,43)$. Although the OVLT area contains most of the cFosexpressing GnRH neurons, they are found anywhere on the continuum caudal to the OVLT $(41,43)$. cFos-labeled GnRH neurons exhibit higher spine density (44), indicating increased inputs at the time of the surge. Furthermore, GnRH neurons display entwined dendrites with shared synapses (45), revealing common inputs, despite scattered cell bodies.

Although the surge is not regulated by a single neuronal population (40) and involves cells at the ME (46), kisspeptin is a powerful stimulator of $\mathrm{GnRH}$ neurons $(47,48)$ and direct inputs to $\mathrm{GnRH}$ neurons, via GPR54, is necessary (31). The RP3V neuronal subpopulation, larger in females and upregulated by estradiol (32), plays a critical role in the activation of $\mathrm{GnRH}$ neurons involved in the surge (49). Notably, although physiologically the preovulatory surge is only observed in females, it is not an intrinsic ability of female $\mathrm{GnRH}$ neurons but the consequence of female-specific inputs to GnRH neurons. RP3V kisspeptin neurons undergo sex-specific neonatal (50) and prepubertal (51) development, orchestrated by testosterone and estradiol, respectively. Hormonal perturbations altering the sexual dimorphism of RP3V result in LH surges in males and loss of LH surge in females (52). 


\section{GnRH Pulsatility}

Gonadectomy releases the HPG axis from sex steroid negative feedback and reveals regular GnRH pulses (53-56). Pulsatility is a critical feature of $\mathrm{GnRH}$ secretion and is required for LH secretion $(57,58)$, underlying LH pulses (59). To date, GnRH pulsatility is still a confounding fact: how do scattered $\mathrm{GnRH}$ neurons synchronize to generate pulses? Two possibilities for a pulse generator exist: intrinsic, i.e., $\mathrm{GnRH}$ neurons generate pulses on their own or extrinsic, i.e., GnRH neurons are driven by other cell type(s). In the first scenario, synchronization requires connectivity between $\mathrm{GnRH}$ neurons, direct or indirect. In the second scenario, synchronization requires connections from a pulse generator to GnRH neurons.

\section{Intrinsic Pulse Generator}

The hypothesis of an intrinsic pulse generator comes from in vitro models for GnRH neurons: (1) mouse cell lines obtained by immortalization, GT1 (60), and (2) primary GnRH cells maintained in organotypic cultures of olfactory placodes, i.e., nasal explants (61-64). Without CNS inputs, these models exhibit pulsatile release of GnRH [GT1 (65-67); nasal explants $(64,68-70)]$. One caveat is that nasal explants contain GABAergic and glutamatergic neurons that influence $\mathrm{GnRH}$ neuronal activity $(71,72)$. In both models, GnRH neurons exhibit action potentials (APs) $(71,73,74)$ and fluctuations of intracellular calcium concentration $\left(\left[\mathrm{Ca}^{2+}\right]_{\mathrm{i}}\right)(75-77)$, concomitant with bursts of APs (78). GnRH neurons in nasal explants also exhibit synchronized $\left[\mathrm{Ca}^{2+}\right]_{\mathrm{i}}$ oscillations $(76,77)$, supporting connectivity between GnRH neurons.

In immortalized cell lines, gap junctions mediate electrical coupling between $\mathrm{GnRH}$ neurons (79-81). Both $\left[\mathrm{Ca}^{2+}\right]_{\mathrm{i}}$ waves across GT1 cells (82) and pulsatile GnRH release (80) are gap junction dependent. However, this mechanism might be an adaptation of GT1 cells (83) since in vivo data reject coupling between $\mathrm{GnRH}$ neurons $(84,85)$. However, gap junctions between GnRH neurons (84) and surrounding cells (86) could allow signal propagation from one GnRH neuron to another and contribute to the synchronicity. In nasal explants, non-neuronal cells exhibit $\left[\mathrm{Ca}^{2+}\right]_{\mathrm{i}}$ oscillations (87) and blocking gap junctions impairs $\mathrm{GnRH}$ secretion (86). Hypothetically, if GnRH neurons were electrically connected in vivo, electrical activation of a subpopulation of $\mathrm{GnRH}$ neurons should propagate through the entire population and evoke an all-or-none GnRH/LH secretory response. However, a linear relationship exists between the number of optogenetically activated GnRH neurons and amplitude of LH pulse, refuting the hypothesis (88).

The alternative to electrical coupling is chemical coupling. GT1 cells on two coverslips within the same chamber exhibit a GnRH secretion profile identical to that of single coverslips, suggesting synchronization through diffusible molecules (66), such as adenosine triphosphate (ATP) or nitric oxide (NO). In vivo GnRH neurons express P2X purinoreceptors $(89,90)$. In nasal explants, ATP contributes to synchronization of GnRH neurons via $\mathrm{P} 2 \mathrm{X}$ receptors (91), but not basal GnRH neuronal activity (72). In agreement, ATP facilitates, but does not evoke, GnRH release from isolated $\mathrm{MBH}$ (92). No physiological data support or refute the role of ATP. While NO contributes to pulsatile secretion at the ME ex vivo $(93,94), \mathrm{NO}$ is released at the time of the surge in vivo $(95,96)$. Notably, GnRH neurons do not express NO synthase (NOS) (97), but NO might contribute to the synchronicity of $\mathrm{GnRH}$ neurons by modulating their firing in the POA (98). Both NO actions in the ME, via endothelial NOS $(99,100)$, and in the POA, via neuronal $\operatorname{NOS}(98,101,102)$, provide examples of cooperative microenvironments. However, GnRH neurons do not initiate the signal and the second possibility of other cell type(s) driving GnRH neurons dominates.

\section{Extrinsic Pulse Generator}

In vitro ARC-ME fragments exhibit pulsatile release of $\mathrm{GnRH}$ (103) and in vivo data support the role of the ARC in GnRH pulsatility (104). Increases in the frequency of multiunit activity (MUA) in the ARC are concomitant with LH pulses (105-107). The nature of the cells generating MUA volleys is unknown, but $\mathrm{GnRH}$ neurons or GnRH en passant fibers are not responsible for them. Estradiol-triggered GnRH surges (107) or kisspeptinevoked GnRH secretion (108) do not trigger MUA volleys.

Mentioned earlier, the ARC kisspeptin subpopulation is proposed as a pulse generator [reviewed in Ref. (109)]. This subpopulation is not sexually dimorphic and is downregulated by sex steroids $(32,33)$. These kisspeptin neurons are the central players of an autoregenerative pulsing model. The two peptides they co-express, neurokinin B and dynorphin, are autocrine modulators providing on-/off-switches (110-112). Unfortunately, the model seems incomplete: (1) ARC kisspeptin neurons unequivocally provide an on-switch for GnRH neurons (113), but not an off-switch; kisspeptin evokes long-lasting electrical and calcium responses in GnRH neurons $(47,48,114,115)$, yet only a short activation produces a LH surge (88), (2) neurokinin B evokes GnRH secretion in kisspeptin knockout mice (116), and (3) neurokinin B is present in kisspeptin neurons in humans but dynorphin is not, thus the pulse generator might be species dependent (117). The model might be more convoluted since ARC and RP3V kisspeptin neurons are interconnected (118), co-express glutamate or GABA, respectively (119) and ARC kisspeptin neurons activate GnRH neurons by stimulating RP3V kisspeptin neurons via glutamatergic release (112). Thus, the mystery of GnRH pulses remains.

\section{FROM GnRH NEURONAL ACTIVITY TO GnRH SECRETION}

Elucidating how pulsatile GnRH secretion occurs is the key to understanding reproductive neuroendocrinology. However, measuring GnRH secretion is difficult. The GnRH neuronal population is small and a subset generates a pulse, therefore the amount of released GnRH is near threshold detection, even with sensitive radioimmunoassay (70). In addition, access to the hypophyseal portal system requires complex surgery and apparatus $(53,120-122)$, incompatible with the mouse. Finally, a half-life of GnRH is only 2-4 min. Thus, LH secretion, amplifying and diffusing the GnRH signal to the systemic circulation, is commonly used as a mirror of GnRH secretion $(121,123)$. However, pulsatile GnRH/LH release requires serial sampling and even LH measurements are hardly achievable with mouse 


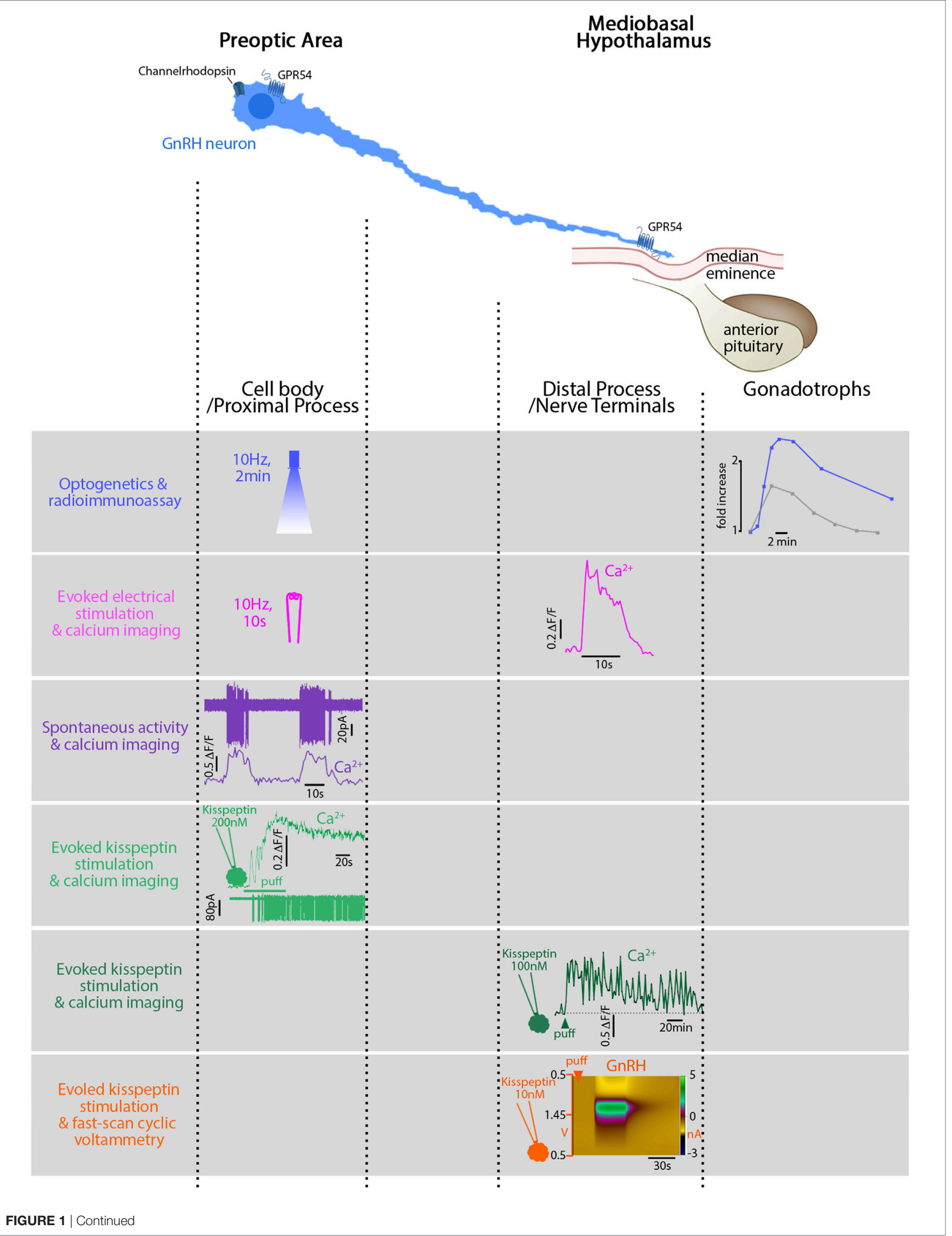


FIGURE 1 | Continued

Relationship between electrical activity, intracellular calcium, and secretion in gonadotropin-releasing hormone (GnRH) neurons in mice. GnRH neurons can be divided into two main functional segments: cell body/proximal process, mainly in the preoptic area (POA), and distal process/nerve terminals, in the mediobasal hypothalamus. First row: blue light, flashed in the POA, electrically activates GnRH neurons expressing channelrhodopsin in vivo. The functional read-out reflecting $\mathrm{GnRH}$ secretion is the luteinizing hormone $(\mathrm{LH})$ increase (blue trace) in the systemic circulation evoked by the gonadotrophs. The gray trace shows a spontaneously occurring LH pulse, much smaller. Second row: electrical stimulation of GnRH fibers activates GnRH neurons expressing genetically encoded calcium sensor GCaMP3 in vitro and evokes a calcium rise in the nerve terminals. Note the stimulus-restricted calcium increase. Third row: spontaneous action currents at the cell body evoke simultaneous rises in $\left[\mathrm{Ca}^{2+}\right]$. Note: the difference between the frequency of spontaneous events (10 s, every $\left.30 \mathrm{~s}\right)$ and the frequency of spontaneously occurring LH pulses [every $21 \mathrm{~min}$ in ovariectomized mice (124)]. Fourth row: Kisspeptin, locally applied at the cell body, binds to its cognate receptor, GPR54, and evokes a long-lasting calcium rise and train of action potentials (APs). Fifth row: Kisspeptin, locally applied at the nerve terminals, evokes a long-lasting calcium rise (>60 min) in GnRH neurons expressing genetically encoded calcium sensor GCaMP6s but no APs are required. Sixth row: Kisspeptin, locally applied at the nerve terminals, evokes secretion ( 1 min). Figures adapted with permission of the authors [row 1 (88); row 2-5 (115); row 6 (141)].

blood volume (124). At a cellular level, the first challenge is anatomical: preserving the connectivity with relevant inputs (125), GnRH cell morphology (126), and tracking a neuron within the complexity of the ME (20). The second challenge is technical as methods for detection of quantal secretion are not applicable to GnRH neurons: (1) synaptically coupled neurons are recorded simultaneously in brain slices [reviewed in Ref. (127)], but GnRH neurons lack downstream partners, (2) patch clamp measurement of capacitive current is limited to soma and isolated nerve terminals $(128,129)$, therefore does not reflect hypophysiotropic GnRH secretion, and (3) fast-scan cyclic voltammetry (FSCV) is restricted to electrochemically active small neurotransmitters [reviewed in Ref. (130)].

Since techniques directly monitoring secretion cannot be applied to GnRH neurons, the alternative is to rely on the relationship between electrical activity, voltage-gated calcium channels, calcium, and secretion [reviewed in Ref. (131)] and use electrophysiology and calcium imaging of the GnRH cell bodies to assess GnRH secretion indirectly. The hypothesis of pulsatile secretion being intrinsic to $\mathrm{GnRH}$ neurons led to studies of electrical properties in GnRH neurons \{GT1 cells (73); nasal explants (71); ex vivo GnRH neurons [reviewed in Ref. $(40,132,133)]\}$. Although most GnRH neurons display autonomous firing of APs, firing is heterogeneous among $\mathrm{GnRH}$ neurons (126), far from an oscillatory activity that could trigger pulses every $\sim 20 \mathrm{~min}$ (124). Even in vivo GnRH neurons exhibit heterogeneous behavior (114). The search for changes in the firing pattern exvivo, i.e., increases in firing rate occurring at the same frequency as GnRH pulses, is rather inconclusive (134-136). Notably, in addition to intrinsic properties, it is assumed that each $\mathrm{GnRH}$ neuron contributes to consecutive $\mathrm{GnRH}$ pulses. Although experimentally activated GnRH neurons can trigger multiple $\mathrm{LH}$ pulses (88), this assumption has yet to be proven.

Simultaneous recording from multiple $\mathrm{GnRH}$ neurons bypasses this assumption and shows in vitro relationships between synchronized $\left[\mathrm{Ca}^{2+}\right]_{\mathrm{i}}$ oscillations and $\mathrm{GnRH}$ pulses (70) or frequency of $\left[\mathrm{Ca}^{2+}\right]_{\mathrm{i}}$ oscillations and $\mathrm{GnRH}$ secretion (137). Recently, optogenetic activation of GnRH neurons defined the firing of $\mathrm{GnRH}$ neurons triggering $\mathrm{LH}$ secretion in vivo (88) (Figure 1). However, the predicament to linking an electrical event to a secretion, at a single-cell level, is the resolution for the detection of GnRH release. Calcium dynamics in GT1 cells correlate with FM1-43 uptake, i.e., secretion (138), but this observation cannot be extrapolated to native GnRH neurons with complex morphology and where GnRH release occurs from cell bodies and fibers $(139,140)$.

Modified FSCV, applicable to GnRH, is a step forward, providing secretion data from one to few GnRH neurons (140). It supports, at a smaller scale, the relationship between APs and secretion: increased firing rate evoked by hormonal status, recorded at the cell body (142), correlates with increased secretion, at the ME (140), highlighting the regulation of firing activity. Most importantly, it allows subcellular measurements and shows a site-specific regulation of $\mathrm{GnRH}$ release (141). Different regulation of somatodendritic and nerve terminal release is known in magnocellular neurons (143), but a new insight in GnRH neurons. In the POA (at bundles of proximal processes), increases in $\left[\mathrm{Ca}^{2+}\right]_{\mathrm{i}}$ evoked by sarco/endoplasmic reticulum calcium-ATPase blocker evoke GnRH release. While in the ME (at nerve terminals), APs must accompany such increases to evoke GnRH release (141). In addition, locally applied inositol triphosphate receptor blocker prevents kisspeptin-evoked $\mathrm{GnRH}$ release in the ME but not in the POA. In contrast, locally applied calcium channel blocker prevents kisspeptin-evoked GnRH release in the POA but not in the ME, where calcium and sodium channel blockers are necessary (141).

Subcellular electrophysiology and calcium imaging identify different functions at different locations in $\mathrm{GnRH}$ neurons $(20,115,144)$ (Figure 1). APs initiate in the proximal process (144) and patterning occurs at the cell soma (145). APs propagate along the process (144) and elicit temporally restricted calcium rises at the nerve terminals (115). The activation of GnRH neurons in the POA triggering a $\mathrm{GnRH} / \mathrm{LH}$ pulse in vivo illustrates this phenomenon (88). However, the straightforwardness stops with electrical stimuli. GnRH neurons become versatile when exposed to ligands. GnRH projections exhibit unique properties allowing local depolarizations to reshape APs along the way to the ME (20). Applied at the cell body, kisspeptin evokes a calcium rise, accompanied by APs (115). Although the calcium rise at the cell body is independent of firing $(48,115,141)$, APs will travel and evoke a spike-dependent calcium rise at the nerve terminals (115). Applied at the nerve terminals, kisspeptin evokes a local calcium rise, independent of APs (115), and triggers GnRH secretion, even when sodium channel blockers are present (141).

Until today, the conundrum was with kisspeptin producing both a massive surge and timely restricted pulses. However, subcellular regulation in GnRH neurons provides new hypotheses for GnRH secretion (Figure 2). RP3V kisspeptin neurons 


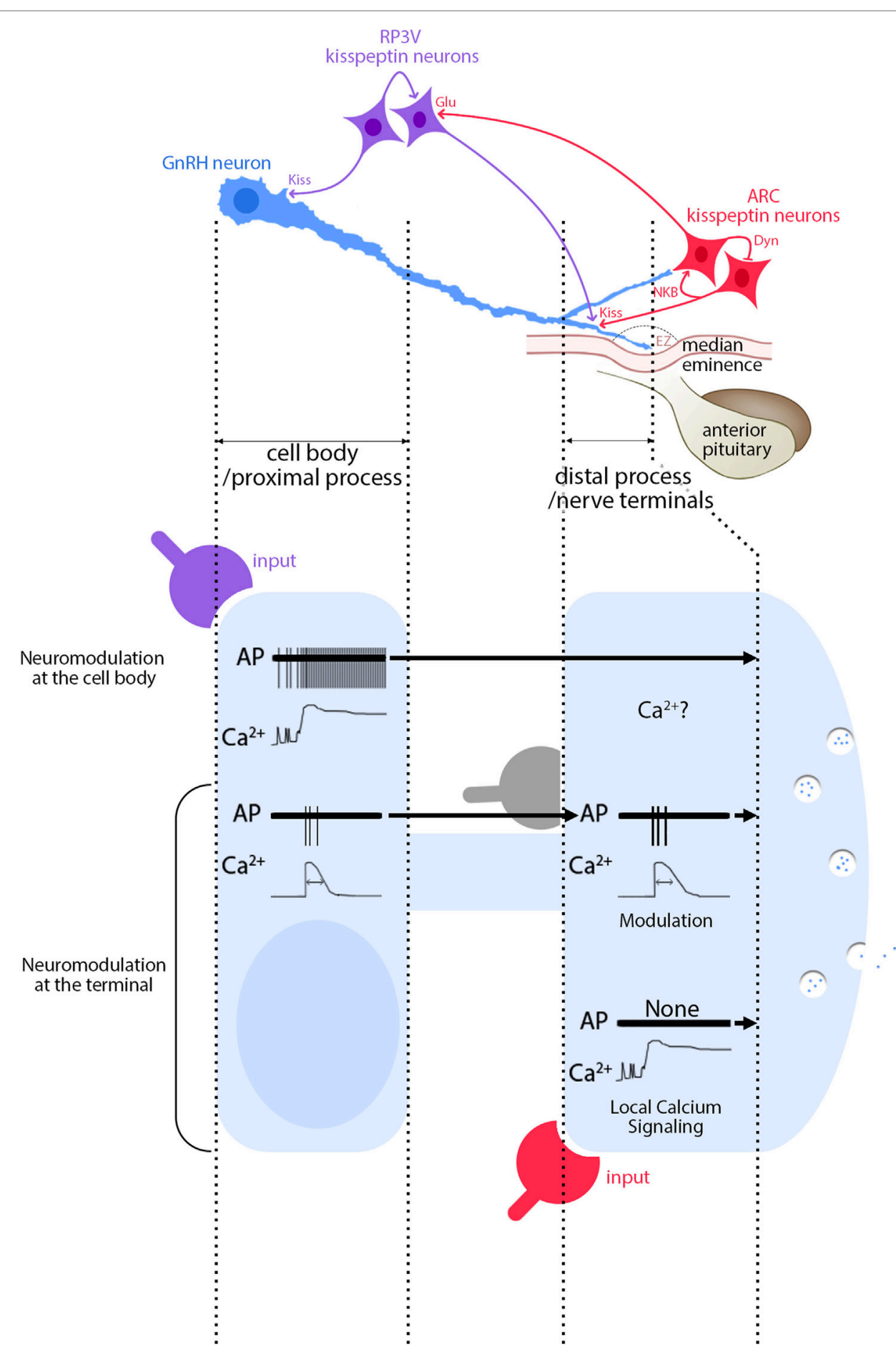

FIGURE 2 | Functional consequences of segment-specific signaling in gonadotropin-releasing hormone (GnRH) neurons. Kisspeptin/GnRH signaling: GnRH neurons (blue) receive inputs from RP3V kisspeptin neurons (purple) at the cell body and at the distal process, outside the external zone (EZ) of the median eminence. In contrast, inputs from ARC kisspeptin neurons (red) are seen only at the distal process. Inputs from ARC to RP3V kisspeptin neurons are glutamatergic. Activity of ARC kisspeptin neurons relies upon an autoregulatory loop involving neurokinin B and dynorphin A. High magnification view of events: signals evoked at GnRH soma from RP3V kisspeptin neurons (purple) produce a long-lasting calcium rise and a train of action potentials (APs) that travel toward the nerve terminals (top traces). Based on Figure $\mathbf{1}$ (second row), an AP-dependent calcium rise would be expected, unless the calcium rise via GPR54 is autoregenerative, travels along the process and therefore would be AP independent. In contrast, signaling evoked at GnRH nerve terminals from ARC kisspeptin neurons (red) produces a long-lasting calcium rise, without APs (bottom traces). In addition, APs, accompanied by AP-dependent calcium rises, travel toward the nerve terminals and modulatory inputs such as glutamate (gray) can reshape the APs and possibly the concomitant calcium rises (middle traces). The traces are schematic and do not have scale bars. 
innervating the GnRH cell body (118) probably initiate different response than ARC kisspeptin neurons innervating the nerve terminals (118), thus regulating GnRH secretion differently. For example, kisspeptin evokes a long-lasting calcium rise in nerve terminals (>60 min) (115) but FSCV detects GnRH release for $\sim 1$ min (141). Possibly, non-secreting calcium-dependent vesicle dynamics might follow calcium-evoked GnRH secretion at the nerve terminals $(115,129,146)$. FSCV indicates kisspeptinevoked secretion at the $\mathrm{ME}$ is specifically regulated and an increase in $\left[\mathrm{Ca}^{2+}\right]_{\mathrm{i}}$ is not the only requirement (141). Exocytosis involves many protein-protein interactions regulated by second messengers and phosphorylation (147). Kisspeptin triggers a complex signaling pathway $(48,148)$ that might allow it to define the relationship between calcium and secretion at $\mathrm{GnRH}$ nerve terminals.

\section{CONCLUSION}

Our knowledge of the physiology of GnRH neurons is ever evolving and we should remain as naïve as possible when studying them. As in many other fields, the knowledge is limited by techniques and none of the "classical" tools available in neuroscience are readily usable for GnRH neurons. Even nowadays, the knowledge of GnRH neurons still suffers from the anatomical intricacy of the system. However, with creativity and tenacity, knowledge about GnRH neurons builds up and common assumptions fall: the simple bipolar GnRH neuron displays arborized distal processes,

\section{REFERENCES}

1. Schwanzel-Fukuda M, Pfaff DW. Origin of luteinizing hormone-releasing hormone neurons. Nature (1989) 338(6211):161-4. doi:10.1038/338161a0

2. Wray S, Grant P, Gainer H. Evidence that cells expressing luteinizing hormone-releasing hormone mRNA in the mouse are derived from progenitor cells in the olfactory placode. Proc Natl Acad Sci U S A (1989) 86(20):8132-6. doi:10.1073/pnas.86.20.8132

3. Wray S. Development of gonadotropin-releasing hormone-1 neurons. Front Neuroendocrinol (2002) 23(3):292-316. doi:10.1016/S0091-3022(02) 00001-8

4. Forni PE, Wray S. GnRH, anosmia and hypogonadotropic hypogonadism where are we? Front Neuroendocrinol (2014) 36:165-77. doi:10.1016/j. yfrne.2014.09.004

5. Barry J. Immunohistochemistry of luteinizing hormone-releasing hormoneproducing neurons of the vertebrates. Int Rev Cytol (1979) 60:179-221. doi:10.1016/S0074-7696(08)61263-2

6. Merchenthaler I, Kovacs G, Lavasz G, Setalo G. The preopticoinfundibular LH-RH tract of the rat. Brain Res (1980) 198(1):63-74. doi:10.1016/0006-8993(80)90344-3

7. Hoffman GE, Finch CE. LHRH neurons in the female C57BL/6J mouse brain during reproductive aging: no loss up to middle age. Neurobiol Aging (1986) 7(1):45-8. doi:10.1016/0197-4580(86)90026-6

8. Wray S, Hoffman G. A developmental study of the quantitative distribution of LHRH neurons within the central nervous system of postnatal male and female rats. J Comp Neurol (1986) 252(4):522-31. doi:10.1002/cne. 902520408

9. Silverman AJ, Antunes JL, Ferin M, Zimmerman EA. The distribution of luteinizing hormone-releasing hormone (LHRH) in the hypothalamus of the rhesus monkey. Light microscopic studies using immunoperoxidase technique. Endocrinology (1977) 101(1):134-42. doi:10.1210/endo-101-1-134

10. Silverman AJ, Antunes JL, Abrams GM, Nilaver G, Thau R, Robinson JA, et al. The luteinizing hormone-releasing hormone pathways in rhesus (Macaca mulatta) and pigtailed (Macaca nemestrina) monkeys: new observations the scattered cell bodies are reunited with entwined dendrites, $\mathrm{GnRH}$ is released at the cell body, the processes become dendrons with merged features of axon and dendrite, and neuronal inputs relocate into differentially regulated GnRH neuron segments. I am positive the list will continue to grow as we try and understand the mechanism(s) underlying pulsatile GnRH secretion.

What do we need to unravel the mystery behind GnRH secretion? I believe the next step is to tailor genetic tools to target genetically encoded sensors such as GCaMP6s and pHuji, to GnRH neurons for simultaneous imaging of calcium dynamics and secretory vesicle fusion. This should allow for the deciphering of their precise relationship and the investigation of how intracellular signaling pathways downstream of GPCRs and other receptors can modulate this relationship.

\section{AUTHOR CONTRIBUTIONS}

The author confirms being the sole contributor of this work approved it for publication.

\section{ACKNOWLEDGMENTS}

I am very grateful to Dr. Susan Wray for her review of the manuscript and to Dr. Stanko Stojilkovic for his valuable comments. This work was supported by the Intramural Research Program of the National Institutes of Health, National Institute of Neurological Disorders and Stroke (grant number: ZIA NS002824-27).

on thick, unembedded sections. JComp Neurol (1982) 211(3):309-17. doi:10.1002/cne.902110309

11. Mason AJ, Hayflick JS, Zoeller RT, Young WS III, Phillips HS, Nikolics K, et al. A deletion truncating the gonadotropin-releasing hormone gene is responsible for hypogonadism in the hpg mouse. Science (1986) 234 (4782):1366-71. doi:10.1126/science.3024317

12. Krieger DT, Perlow MJ, Gibson MJ, Davies TF, Zimmerman EA, Ferin M, et al. Brain grafts reverse hypogonadism of gonadotropin releasing hormone deficiency. Nature (1982) 298(5873):468-71. doi:10.1038/298468a0

13. Gibson MJ, Krieger DT, Charlton HM, Zimmerman EA, Silverman AJ, Perlow MJ. Mating and pregnancy can occur in genetically hypogonadal mice with preoptic area brain grafts. Science (1984) 225(4665):949-51. doi:10.1126/science.6382608

14. Saitoh Y, Luchansky LL, Claude P, Terasawa E. Transplantation of the fetal olfactory placode restores reproductive cycles in female rhesus monkeys (Mucaca mulatta) bearing lesions in the medial basal hypothalamus. Endocrinology (1995) 136(6):2760-9. doi:10.1210/endo.136.6.7750501

15. Charlton H. Neural transplantation in hypogonadal (hpg) mice - physiology and neurobiology. Reproduction (2004) 127(1):3-12. doi:10.1530/rep.1.00066

16. Gibson MJ, Moscovitz HC, Kokoris GJ, Silverman AJ. Plasma LH rises rapidly following mating in hypogonadal female mice with preoptic area (POA) brain grafts. Brain Res (1987) 424(1):133-8. doi:10.1016/0006-8993(87) 91202-9

17. Gill JC, Wang O, Kakar S, Martinelli E, Carroll RS, Kaiser UB. Reproductive hormone-dependent and -independent contributions to developmental changes in kisspeptin in GnRH-deficient hypogonadal mice. PLoS One (2010) 5(7):e11911. doi:10.1371/journal.pone.0011911

18. Witkin JW. Access of luteinizing hormone-releasing hormone neurons to the vasculature in the rat. Neuroscience (1990) 37(2):501-6. doi:10.1016/0306-4522(90)90417-3

19. Silverman AJ, Witkin JW, Silverman RC, Gibson MJ. Modulation of gonadotropin-releasing hormone neuronal activity as evidenced by uptake of fluorogold from the vasculature. Synapse (1990) 6(2):154-60. doi:10.1002/ syn. 890060206 
20. Herde $\mathrm{M}$, Iremonger $\mathrm{K}$, Constantin S, Herbison A. GnRH neurons elaborate a long-range projection with shared axonal and dendritic functions. J Neurosci (2013) 33(31):12689-97. doi:10.1523/JNEUROSCI.057913.2013

21. Herde MK, Geist K, Campbell RE, Herbison AE. Gonadotropin-releasing hormone neurons extend complex highly branched dendritic trees outside the blood-brain barrier. Endocrinology (2011) 152(10):3832-41. doi:10.1210/ en.2011-1228

22. Silverman AJ, Jhamandas J, Renaud LP. Localization of luteinizing hormone-releasing hormone (LHRH) neurons that project to the median eminence. J Neurosci (1987) 7(8):2312-9.

23. Herbison AE, Porteous R, Pape JR, Mora JM, Hurst PR. Gonadotropinreleasing hormone neuron requirements for puberty, ovulation, and fertility. Endocrinology (2008) 149(2):597-604. doi:10.1210/en.2007-1139

24. Witkin JW, Paden CM, Silverman AJ. The luteinizing hormone-releasing hormone (LHRH) systems in the rat brain. Neuroendocrinology (1982) 35(6):429-38. doi:10.1159/000123419

25. Wen S, Gotze IN, Mai O, Schauer C, Leinders-Zufall T, Boehm U. Genetic identification of $\mathrm{GnRH}$ receptor neurons: a new model for studying neural circuits underlying reproductive physiology in the mouse brain. Endocrinology (2011) 152(4):1515-26. doi:10.1210/en.2010-1208

26. Prevot V. Puberty in mice and rats. In: Knobil E, Neill J, editors. Knobil and Neill's Physiology of Reproduction. San Diego, CA: Elsevier (2015). p. 1395-439.

27. Herbison AE. Control of puberty onset and fertility by gonadotropinreleasing hormone neurons. Nat Rev Endocrinol (2016) 12(8):452-66. doi: $10.1038 /$ nrendo. 2016.70

28. Seminara SB, Messager S, Chatzidaki EE, Thresher RR, Acierno JS Jr, Shagoury JK, et al. The GPR54 gene as a regulator of puberty. $N$ Engl J Med (2003) 349(17):1614-27. doi:10.1056/NEJMoa035322

29. de Roux N, Genin E, Carel JC, Matsuda F, Chaussain JL, Milgrom E. Hypogonadotropichypogonadism due to loss of function of the KiSS1-derived peptide receptor GPR54. Proc Natl Acad Sci U S A (2003) 100(19):10972-6. doi:10.1073/pnas.1834399100

30. d'Anglemont de Tassigny X, Fagg LA, Dixon JP, Day K, Leitch HG, Hendrick AG, et al. Hypogonadotropic hypogonadism in mice lacking a functional Kiss1 gene. Proc Natl Acad Sci U S A (2007) 104(25):10714-9. doi:10.1073/pnas.0704114104

31. Kirilov M, Clarkson J, Liu X, Roa J, Campos P, Porteous R, et al. Dependence of fertility on kisspeptin-Gpr54 signaling at the GnRH neuron. Nat Commun (2013) 4:2492. doi:10.1038/ncomms3492

32. Smith JT, Cunningham MJ, Rissman EF, Clifton DK, Steiner RA. Regulation of Kiss1 gene expression in the brain of the female mouse. Endocrinology (2005) 146(9):3686-92. doi:10.1210/en.2005-0323

33. Smith JT, Dungan HM, Stoll EA, Gottsch ML, Braun RE, Eacker SM, et al. Differential regulation of KiSS-1 mRNA expression by sex steroids in the brain of the male mouse. Endocrinology (2005) 146(7):2976-84. doi:10.1210/ en.2005-0323

34. Herbison AE, Pape JR. New evidence for estrogen receptors in gonadotropinreleasing hormone neurons. Front Neuroendocrinol (2001) 22(4):292-308. doi:10.1006/frne.2001.0219

35. Sharifi N, Reuss AE, Wray S. Prenatal LHRH neurons in nasal explant cultures express estrogen receptor beta transcript. Endocrinology (2002) 143(7):2503-7. doi:10.1210/endo.143.7.8897

36. Cheong RY, Porteous R, Chambon P, Abraham I, Herbison AE. Effects of neuron-specific estrogen receptor (ER) alpha and ERbeta deletion on the acute estrogen negative feedback mechanism in adult female mice. Endocrinology (2014) 155(4):1418-27. doi:10.1210/en.2013-1943

37. Leon S, Barroso A, Vazquez MJ, Garcia-Galiano D, Manfredi-Lozano M, Ruiz-Pino F, et al. Direct actions of kisspeptins on GnRH neurons permit attainment of fertility but are insufficient to fully preserve gonadotropic axis activity. Sci Rep (2016) 6:19206. doi:10.1038/srep19206

38. Goodman RL, Lehman MN. Kisspeptin neurons from mice to men: similarities and differences. Endocrinology (2012) 153(11):5105-18. doi:10.1210/ en.2012-1550

39. Christian CA, Moenter SM. The neurobiology of preovulatory and estradiol-induced gonadotropin-releasing hormone surges. Endocr Rev (2010) 31(4):544-77. doi:10.1210/er.2009-0023
40. Herbison AE. Physiology of the adult gonadotropin-releasing hormone neuronal network. 4th ed. In: Knobil E, Neill J, editors. Knobil and Neill's Physiology of Reproduction. San Diego, CA: Elsevier (2015). p.399-467.

41. Lee WS, Smith MS, Hoffman GE. Luteinizing hormone-releasing hormone neurons express Fos protein during the proestrous surge of luteinizing hormone. Proc Natl Acad Sci U S A (1990) 87(13):5163-7. doi:10.1073/pnas. 87.13.5163

42. Lee WS, Abbud R, Smith MS, Hoffman GE. LHRH neurons express cJun protein during the proestrous surge of luteinizing hormone. Endocrinology (1992) 130(5):3101-3. doi:10.1210/endo.130.5.1572316

43. Wintermantel TM, Campbell RE, Porteous R, Bock D, Grone HJ, Todman MG, et al. Definition of estrogen receptor pathway critical for estrogen positive feedback to gonadotropin-releasing hormone neurons and fertility. Neuron (2006) 52(2):271-80. doi:10.1016/j.neuron.2006.07.023

44. Chan H, Prescott M, Ong Z, Herde MK, Herbison AE, Campbell RE. Dendritic spine plasticity in gonadotropin-releasing hormone $(\mathrm{GnRH})$ neurons activated at the time of the preovulatory surge. Endocrinology (2011) 152(12):4906-14. doi:10.1210/en.2011-1522

45. Campbell RE, Gaidamaka G, Han SK, Herbison AE. Dendro-dendritic bundling and shared synapses between gonadotropin-releasing hormone neurons. Proc Natl Acad Sci U S A (2009) 106(26):10835-40. doi:10.1073/ pnas.0903463106

46. Prevot V, Hanchate NK, Bellefontaine N, Sharif A, Parkash J, Estrella C, et al. Function-related structural plasticity of the GnRH system: a role for neuronal-glial-endothelial interactions. Front Neuroendocrinol (2010) 31(3):241-58. doi:10.1016/j.yfrne.2010.05.003

47. Han SK, Gottsch ML, Lee KJ, Popa SM, Smith JT, Jakawich SK, et al. Activation of gonadotropin-releasing hormone neurons by kisspeptin as a neuroendocrine switch for the onset of puberty. JNeurosci (2005) 25(49):11349-56. doi:10.1523/JNEUROSCI.3328-05.2005

48. Constantin S, Caligioni CS, Stojilkovic S, Wray S. Kisspeptin-10 facilitates a plasma membrane-driven calcium oscillator in GnRH-1 neurons. Endocrinology (2009) 150(3):1400-12. doi:10.1210/en.2008-0979

49. Clarkson J, d'Anglemont de Tassigny X, Moreno AS, Colledge WH, Herbison AE. Kisspeptin-GPR54 signaling is essential for preovulatory gonadotropin-releasing hormone neuron activation and the luteinizing hormone surge. J Neurosci (2008) 28(35):8691-7. doi:10.1523/jneurosci.177508.2008

50. Clarkson J, Busby ER, Kirilov M, Schutz G, Sherwood NM, Herbison AE. Sexual differentiation of the brain requires perinatal kisspeptin-GnRH neuron signaling. J Neurosci (2014) 34(46):15297-305. doi:10.1523/jneurosci. 3061-14.2014

51. Clarkson J, Boon WC, Simpson ER, Herbison AE. Postnatal development of an estradiol-kisspeptin positive feedback mechanism implicated in puberty onset. Endocrinology (2009) 150(7):3214-20. doi:10.1210/en.2008-1733

52. Homma T, Sakakibara M, Yamada S, Kinoshita M, Iwata K, Tomikawa J, et al. Significance of neonatal testicular sex steroids to defeminize anteroventral periventricular kisspeptin neurons and the GnRH/LH surge system in male rats. Biol Reprod (2009) 81(6):1216-25. doi:10.1095/biolreprod.109.078311

53. Carmel PW, Araki S, Ferin M. Pituitary stalk portal blood collection in rhesus monkeys: evidence for pulsatile release of gonadotropin-releasing hormone (GnRH). Endocrinology (1976) 99(1):243-8. doi:10.1210/endo-99-1-243

54. Levine JE, Ramirez VD. Luteinizing hormone-releasing hormone release during the rat estrous cycle and after ovariectomy, as estimated with pushpull cannulae. Endocrinology (1982) 111(5):1439-48. doi:10.1210/endo111-5-1439

55. Levine JE, Norman RL, Gliessman PM, Oyama TT, Bangsberg DR, Spies HG. In vivo gonadotropin-releasing hormone release and serum luteinizing hormone measurements in ovariectomized, estrogen-treated rhesus macaques. Endocrinology (1985) 117(2):711-21. doi:10.1210/endo$117-2-711$

56. Caraty A, Locatelli A, Martin GB. Biphasic response in the secretion of gonadotrophin-releasing hormone in ovariectomized ewes injected with oestradiol. J Endocrinol (1989) 123(3):375-82. doi:10.1677/joe.0.1230375

57. Belchetz PE, Plant TM, Nakai Y, Keogh EJ, Knobil E. Hypophysial responses to continuous and intermittent delivery of hypopthalamic gonadotropinreleasing hormone. Science (1978) 202(4368):631-3. doi:10.1126/science. 100883 
58. Wildt L, Hausler A, Marshall G, Hutchison JS, Plant TM, Belchetz PE, et al. Frequency and amplitude of gonadotropin-releasing hormone stimulation and gonadotropin secretion in the rhesus monkey. Endocrinology (1981) 109(2):376-85. doi:10.1210/endo-109-2-376

59. Dierschke DJ, Bhattacharya AN, Atkinson LE, Knobil E. Circhoral oscillations of plasma LH levels in the ovariectomized rhesus monkey. Endocrinology (1970) 87(5):850-3. doi:10.1210/endo-87-5-850

60. Mellon PL, Windle JJ, Goldsmith PC, Padula CA, Roberts JL, Weiner RI. Immortalization of hypothalamic GnRH neurons by genetically targeted tumorigenesis. Neuron (1990) 5(1):1-10. doi:10.1016/ 0896-6273(90)90028-E

61. Terasawa E, Quanbeck CD, Schulz CA, Burich AJ, Luchansky LL, Claude P. A primary cell culture system of luteinizing hormone releasing hormone neurons derived from embryonic olfactory placode in the rhesus monkey. Endocrinology (1993) 133(5):2379-90. doi:10.1210/endo.133.5. 8404690

62. Fueshko S, Wray S. LHRH cells migrate on peripherin fibers in embryonic olfactory explant cultures: an in vitro model for neurophilic neuronal migration. Dev Biol (1994) 166(1):331-48. doi:10.1006/dbio.1994.1319

63. Duittoz AH, Batailler M, Caldani M. Primary cell culture of LHRH neurones from embryonic olfactory placode in the sheep (Ovis aries). J Neuroendocrinol (1997) 9(9):669-75. doi:10.1046/j.1365-2826.1997.00627.x

64. Funabashi T, Daikoku S, Shinohara K, Kimura F. Pulsatile gonadotropinreleasing hormone $(\mathrm{GnRH})$ secretion is an inherent function of $\mathrm{GnRH}$ neurons, as revealed by the culture of medial olfactory placode obtained from embryonic rats. Neuroendocrinology (2000) 71(2):138-44. doi:10.1159/ 000054529

65. Krsmanovic LZ, Stojilkovic SS, Merelli F, Dufour SM, Virmani MA, Catt KJ. Calcium signaling and episodic secretion of gonadotropin-releasing hormone in hypothalamic neurons. Proc Natl Acad Sci U S A (1992) 89(18):8462-6. doi:10.1073/pnas.89.18.8462

66. Martinez de la Escalera G, Choi AL, Weiner RI. Generation and synchronization of gonadotropin-releasing hormone $(\mathrm{GnRH})$ pulses: intrinsic properties of the GT1-1 GnRH neuronal cell line. Proc Natl Acad Sci U S A (1992) 89(5):1852-5. doi:10.1073/pnas.89.5.1852

67. Chappell PE, White RS, Mellon PL. Circadian gene expression regulates pulsatile gonadotropin-releasing hormone $(\mathrm{GnRH})$ secretory patterns in the hypothalamic GnRH-secreting GT1-7 cell line. JNeurosci (2003) 23(35):11202-13.

68. Terasawa E, Keen KL, Mogi K, Claude P. Pulsatile release of luteinizing hormone-releasing hormone (LHRH) in cultured LHRH neurons derived from the embryonic olfactory placode of the rhesus monkey. Endocrinology (1999) 140(3):1432-41. doi:10.1210/endo.140.3.6559

69. Duittoz AH, Batailler M. Pulsatile GnRH secretion from primary cultures of sheep olfactory placode explants. J Reprod Fertil (2000) 120(2):391-6. doi:10.1530/reprod/120.2.391

70. Constantin S, Caraty A, Wray S, Duittoz AH. Development of gonadotropinreleasing hormone-1 secretion in mouse nasal explants. Endocrinology (2009) 150(7):3221-7. doi:10.1210/en.2008-1711

71. Kusano K, Fueshko S, Gainer H, Wray S. Electrical and synaptic properties of embryonic luteinizing hormone-releasing hormone neurons in explant cultures. Proc Natl Acad Sci U S A (1995) 92(9):3918-22. doi:10.1073/ pnas.92.9.3918

72. Constantin S, Klenke U, Wray S. The calcium oscillator of GnRH-1 neurons is developmentally regulated. Endocrinology (2010) 151(8):3863-73. doi:10.1210/en.2010-0118

73. Bosma MM. Ion channel properties and episodic activity in isolated immortalized gonadotropin-releasing hormone ( $\mathrm{GnRH}$ ) neurons. J Membr Biol (1993) 136(1):85-96. doi:10.1007/BF00241492

74. Abe H, Terasawa E. Firing pattern and rapid modulation of activity by estrogen in primate luteinizing hormone releasing hormone-1 neurons. Endocrinology (2005) 146(10):4312-20. doi:10.1210/en.2005-0435

75. Charles AC, Hales TG. Mechanisms of spontaneous calcium oscillations and action potentials in immortalized hypothalamic (GT1-7) neurons. J Neurophysiol (1995) 73(1):56-64.

76. Terasawa E, Schanhofer WK, Keen KL, Luchansky L. Intracellular Ca(2+) oscillations in luteinizing hormone-releasing hormone neurons derived from the embryonic olfactory placode of the rhesus monkey. J Neurosci (1999) 19(14):5898-909.

77. Moore JP Jr, Shang E, Wray S. In situ GABAergic modulation of synchronous gonadotropin releasing hormone-1 neuronal activity. JNeurosci (2002) 22(20):8932-41.

78. Constantin S, Wray S. Gonadotropin-releasing hormone-1 neuronal activity is independent of cyclic nucleotide-gated channels. Endocrinology (2008) 149(1):279-90. doi:10.1210/en.2007-1508

79. Hu L, Olson AJ, Weiner RI, Goldsmith PC. Connexin 26 expression and extensive gap junctional coupling in cultures of GT1-7 cells secreting gonadotropin-releasing hormone. Neuroendocrinology (1999) 70(4):221-7. doi: $10.1159 / 000054480$

80. Bose S, Leclerc GM, Vasquez-Martinez R, Boockfor FR. Administration of connexin43 siRNA abolishes secretory pulse synchronization in GnRH clonal cell populations. Mol Cell Endocrinol (2010) 314(1):75-83 doi:10.1016/j.mce.2009.08.016

81. Vazquez-Martinez R, Shorte SL, Boockfor FR, Frawley LS. Synchronized exocytotic bursts from gonadotropin-releasing hormone-expressing cells: dual control by intrinsic cellular pulsatility and gap junctional communication. Endocrinology (2001) 142(5):2095-101. doi:10.1210/endo.142.5.8123

82. Charles AC, Kodali SK, Tyndale RF. Intercellular calcium waves in neurons. Mol Cell Neurosci (1996) 7(5):337-53. doi:10.1006/mcne.1996.0025

83. Selmanoff M. Commentary on the use of immortalized neuroendocrine cell lines for physiological research. Endocrine (1997) 6(1):1-3. doi:10.1007/ BF02738794

84. Hosny S, Jennes L. Identification of gap junctional connexin-32 mRNA and protein in gonadotropin-releasing hormone neurons of the female rat. Neuroendocrinology (1998) 67(2):101-8. doi:10.1159/000054304

85. Campbell RE, Ducret E, Porteous R, Liu X, Herde MK, Wellerhaus K, et al. Gap junctions between neuronal inputs but not gonadotropin-releasing hormone neurons control estrous cycles in the mouse. Endocrinology (2011) 152(6):2290-301. doi:10.1210/en.2010-1311

86. Pinet-Charvet C, Geller S, Desroziers E, Ottogalli M, Lomet D, Georgelin C, et al. GnRH episodic secretion is altered by pharmacological blockade of gap junctions: possible involvement of glial cells. Endocrinology (2015) 157(1):304-22. doi:10.1210/en.2015-1437

87. Richter TA, Keen KL, Terasawa E. Synchronization of $\mathrm{Ca}(2+)$ oscillations among primate LHRH neurons and nonneuronal cells in vitro. J Neurophysiol (2002) 88(3):1559-67.

88. Campos P, Herbison AE. Optogenetic activation of $\mathrm{GnRH}$ neurons reveals minimal requirements for pulsatile luteinizing hormone secretion. Proc Natl Acad Sci U S A (2014) 111(51):18387-92. doi:10.1073/pnas.1415226112

89. Fu J, Yu Q, Guo W, He C, Burnstock G, Xiang Z. P2X receptors are expressed on neurons containing luteinizing hormone-releasing hormone in the mouse hypothalamus. Neurosci Lett (2009) 458(1):32-6. doi:10.1016/j. neulet.2009.04.017

90. Vastagh C, Rodolosse A, Solymosi N, Liposits Z. Altered expression of genes encoding neurotransmitter receptors in $\mathrm{GnRH}$ neurons of proestrous mice. Front Cell Neurosci (2016) 10:230. doi:10.3389/fncel.2016.00230

91. Terasawa E, Keen KL, Grendell RL, Golos TG. Possible role of 5'-adenosine triphosphate in synchronization of $\mathrm{Ca} 2+$ oscillations in primate luteinizing hormone-releasing hormone neurons. Mol Endocrinol (2005) 19(11): 2736-47. doi:10.1210/me.2005-0034

92. Barnea A, Cho G, Katz BM. A putative role for extracellular ATP: facilitation of 67copper uptake and of copper stimulation of the release of luteinizing hormone-releasing hormone from median eminence explants. Brain Res (1991) 541(1):93-7. doi:10.1016/0006-8993(91)91079-G

93. Moretto M, Lopez FJ, Negro-Vilar A. Nitric oxide regulates luteinizing hormone-releasing hormone secretion. Endocrinology (1993) 133(5): 2399-402. doi:10.1210/endo.133.5.8104781

94. Rettori V, Belova N, Dees WL, Nyberg CL, Gimeno M, McCann SM. Role of nitric oxide in the control of luteinizing hormone-releasing hormone release in vivo and in vitro. Proc Natl Acad Sci U S A (1993) 90(21):10130-4. doi:10.1073/pnas.90.21.10130

95. Knauf C, Ferreira S, Hamdane M, Mailliot C, Prevot V, Beauvillain JC, et al. Variation of endothelial nitric oxide synthase synthesis in the median eminence during the rat estrous cycle: an additional argument for 
the implication of vascular blood vessel in the control of GnRH release. Endocrinology (2001) 142(10):4288-94. doi:10.1210/endo.142.10.8443

96. Knauf C, Prevot V, Stefano GB, Mortreux G, Beauvillain JC, Croix D. Evidence for a spontaneous nitric oxide release from the rat median eminence: influence on gonadotropin-releasing hormone release. Endocrinology (2001) 142(6):2343-50. doi:10.1210/endo.142.6.8073

97. Herbison AE, Simonian SX, Norris PJ, Emson PC. Relationship of neuronal nitric oxide synthase immunoreactivity to GnRH neurons in the ovariectomized and intact female rat. J Neuroendocrinol (1996) 8(1):73-82. doi:10.11 11/j.1365-2826.1996.tb00688.x

98. Clasadonte J, Poulain P, Beauvillain JC, Prevot V. Activation of neuronal nitric oxide release inhibits spontaneous firing in adult gonadotropinreleasing hormone neurons: a possible local synchronizing signal. Endocrinology (2008) 149(2):587-96. doi:10.1210/en.2007-1260

99. Prevot V, Dehouck B, Poulain P, Beauvillain JC, Buee-Scherrer V, Bouret S. Neuronal-glial-endothelial interactions and cell plasticity in the postnatal hypothalamus: implications for the neuroendocrine control of reproduction. Psychoneuroendocrinology (2007) 32(Suppl 1):S46-51. doi:10.1016/j. psyneuen.2007.03.018

100. de Seranno S, d'Anglemont de Tassigny X, Estrella C, Loyens A, Kasparov S, Leroy D, et al. Role of estradiol in the dynamic control of tanycyte plasticity mediated by vascular endothelial cells in the median eminence. Endocrinology (2010) 151(4):1760-72. doi:10.1210/en.2009-0870

101. Bellefontaine N, Hanchate NK, Parkash J, Campagne C, de Seranno S, Clasadonte J, et al. Nitric oxide as key mediator of neuron-to-neuron and endothelia-to-glia communication involved in the neuroendocrine control of reproduction. Neuroendocrinology (2011) 93(2):74-89. doi:10.1159/ 000324147

102. Hanchate NK, Parkash J, Bellefontaine N, Mazur D, Colledge WH, d'Anglemont de Tassigny X, et al. Kisspeptin-GPR54 signaling in mouse NO-synthesizing neurons participates in the hypothalamic control of ovulation. J Neurosci (2012) 32(3):932-45. doi:10.1523/JNEUROSCI.4765-11.2012

103. Levine JE, Ramirez VD. Measurement of neuropeptide release: in vitro and in vivo procedures. Methods Enzymol (1986) 124:466-94. doi:10.1016/ 0076-6879(86)24035-5

104. Plant TM, Krey LC, Moossy J, McCormack JT, Hess DL, Knobil E. The arcuate nucleus and the control of gonadotropin and prolactin secretion in the female rhesus monkey (Macaca mulatta). Endocrinology (1978) 102(1):52-62. doi:10.1210/endo-102-1-52

105. Knobil E. Patterns of hypophysiotropic signals and gonadotropin secretion in the rhesus monkey. Biol Reprod (1981) 24(1):44-9. doi:10.1095/ biolreprod24.1.44

106. Kawakami M, Uemura T, Hayashi R. Electrophysiological correlates of pulsatile gonadotropin release in rats. Neuroendocrinology (1982) 35(1):63-7. doi:10.1159/000123356

107. Tanaka T, Mori Y, Hoshino K. Hypothalamic GnRH pulse generator activity during the estradiol-induced LH surge in ovariectomized goats. Neuroendocrinology (1992) 56(5):641-5. doi:10.1159/000126287

108. Ohkura S, Takase K, Matsuyama S, Mogi K, Ichimaru T, Wakabayashi Y, et al. Gonadotrophin-releasing hormone pulse generator activity in the hypothalamus of the goat. J Neuroendocrinol (2009) 21(10):813-21. doi:10.1111/j.1365-2826.2009.01909.x

109. Navarro VM. New insights into the control of pulsatile GnRH release: the role of Kiss1/neurokinin B neurons. Front Endocrinol (2012) 3:48. doi:10.3389/fendo.2012.00048

110. Goodman RL, Hileman SM, Nestor CC, Porter KL, Connors JM, Hardy SL, et al. Kisspeptin, neurokinin B, and dynorphin act in the arcuate nucleus to control activity of the GnRH pulse generator in ewes. Endocrinology (2013) 154(11):4259-69. doi:10.1210/en.2013-1331

111. Ruka KA, Burger LL, Moenter SM. Both estrogen and androgen modify the response to activation of neurokinin-3 and kappa-opioid receptors in arcuate kisspeptin neurons from male mice. Endocrinology (2015) 157(2):757-63. doi:10.1210/en.2015-1688

112. Qiu J, Nestor CC, Zhang C, Padilla SL, Palmiter RD, Kelly MJ, et al. High-frequency stimulation-induced peptide release synchronizes arcuate kisspeptin neurons and excites GnRH neurons. Elife (2016) 5:e16246. doi:10.7554/eLife.16246

113. Han SY, McLennan T, Czieselsky K, Herbison AE. Selective optogenetic activation of arcuate kisspeptin neurons generates pulsatile luteinizing hormone secretion. Proc Natl Acad Sci U S A (2015) 112(42):13109-14. doi:10.1073/pnas.1512243112

114. Constantin S, Iremonger KJ, Herbison AE. In vivo recordings of GnRH neuron firing reveal heterogeneity and dependence upon GABAA receptor signaling.J Neurosci(2013)33(22):9394-401.doi:10.1523/JNEUROSCI.053313.2013

115. Iremonger KJ, Porteous R, Herbison AE. Spike and neuropeptide-dependent mechanisms control GnRH neuron nerve terminal Ca2+ over diverse time scales. J Neurosci (2017) 37(12):3342-51. doi:10.1523/jneurosci.292516.2017

116. Gaskins GT, Glanowska KM, Moenter SM. Activation of neurokinin 3 receptors stimulates GnRH release in a location-dependent but kisspeptinindependent manner in adult mice. Endocrinology (2013) 154(11):3984-9. doi:10.1210/en.2013-1479

117. Skrapits K, Borsay BA, Herczeg L, Ciofi P, Liposits Z, Hrabovszky E. Neuropeptide co-expression in hypothalamic kisspeptin neurons of laboratory animals and the human. Front Neurosci (2015) 9:29. doi:10.3389/ fnins.2015.00029

118. Hoong Yip S, Boehm U, Herbison AE, Campbell RE. Conditional viral tract-tracing delineates the projections of the distinct kisspeptin neuron populations to gonadotropin-releasing hormone $(\mathrm{GnRH})$ neurons in the mouse. Endocrinology (2015) 156(17):2582-94. doi:10.1210/en.2015-1131

119. Cravo RM, Margatho LO, Osborne-Lawrence S, Donato J Jr, Atkin S, Bookout AL, et al. Characterization of Kiss1 neurons using transgenic mouse models. Neuroscience (2011) 173:37-56. doi:10.1016/j.neuroscience. 2010.11.022

120. Levine JE, Ramirez VD. In vivo release of luteinizing hormone-releasing hormone estimated with push-pull cannulae from the mediobasal hypothalami of ovariectomized, steroid-primed rats. Endocrinology (1980) 107(6):1782-90. doi:10.1210/endo-107-6-1782

121. Levine JE, Pau KY, Ramirez VD, Jackson GL. Simultaneous measurement of luteinizing hormone-releasing hormone and luteinizing hormone release in unanesthetized, ovariectomized sheep. Endocrinology (1982) 111(5): 1449-55. doi:10.1210/endo-111-5-1449

122. Caraty A, Orgeur P, Thiery JC. [Demonstration of the pulsatile secretion of LH-RH into hypophysial portal blood of ewes using an original technic for multiple samples]. C R Seances Acad Sci III (1982) 295(2):103-6.

123. Xia L, Van Vugt D, Alston EJ, Luckhaus J, Ferin M. A surge of gonadotropinreleasing hormone accompanies the estradiol-induced gonadotropin surge in the rhesus monkey. Endocrinology (1992) 131(6):2812-20. doi:10.1210/ endo.131.6.1446619

124. Czieselsky K, Prescott M, Porteous R, Campos P, Clarkson J, Steyn FJ, et al. Pulse and surge profiles of luteinizing hormone secretion in the mouse. Endocrinology (2016) 157(12):4794-802. doi:10.1210/en.2016-1351

125. Liu X, Porteous R, d'Anglemont de Tassigny X, Colledge WH, Millar R, Petersen SL, et al. Frequency-dependent recruitment of fast amino acid and slow neuropeptide neurotransmitter release controls gonadotropinreleasing hormone neuron excitability. J Neurosci (2011) 31(7):2421-30. doi:10.1523/jneurosci.5759-10.2011

126. Constantin S, Piet R, Iremonger K, Yeo SH, Clarkson J, Porteous R, et al. GnRH neuron firing and response to GABA in vitro depend on acute brain slice thickness and orientation. Endocrinology (2012) 153(8):3758-69. doi:10.1210/en.2012-1126

127. Miles R, Poncer JC. Paired recordings from neurones. Curr Opin Neurobiol (1996) 6(3):387-94. doi:10.1016/S0959-4388(96)80124-3

128. Lim NF, Nowycky MC, Bookman RJ. Direct measurement of exocytosis and calcium currents in single vertebrate nerve terminals. Nature (1990) 344(6265):449-51. doi:10.1038/344449a0

129. Neher E, Zucker RS. Multiple calcium-dependent processes related to secretion in bovine chromaffin cells. Neuron (1993) 10(1):21-30. doi:10.1016/0896-6273(93)90238-M

130. Bucher ES, Wightman RM. Electrochemical analysis of neurotransmitters. Annu Rev Anal Chem (Palo Alto, Calif) (2015) 8:239-61. doi:10.1146/ annurev-anchem-071114-040426

131. Augustine GJ. How does calcium trigger neurotransmitter release? Curr Opin Neurobiol (2001) 11(3):320-6. doi:10.1016/S0959-4388(00)00214-2

132. Kelly MJ, Wagner EJ.GnRH neurons and episodic bursting activity. Trends Endocrinol Metab (2002) 13(10):409-10. doi:10.1016/S1043-2760 (02)00698-7 
133. Moenter SM. Identified GnRH neuron electrophysiology: a decade of study. Brain Res (2010) 1364:10-24. doi:10.1016/j.brainres.2010.09.066

134. Suter KJ, Wuarin JP, Smith BN, Dudek FE, Moenter SM. Whole-cell recordings from preoptic/hypothalamic slices reveal burst firing in gonadotropinreleasing hormone neurons identified with green fluorescent protein in transgenic mice. Endocrinology (2000) 141(10):3731-6. doi:10.1210/endo. 141.10.7690

135. Nunemaker CS, DeFazio RA, Moenter SM. Estradiol-sensitive afferents modulate long-term episodic firing patterns of $\mathrm{GnRH}$ neurons. Endocrinology (2002) 143(6):2284-92. doi:10.1210/endo.143.6.8869

136. Kuehl-Kovarik MC, Pouliot WA, Halterman GL, Handa RJ, Dudek FE, Partin KM. Episodic bursting activity and response to excitatory amino acids in acutely dissociated gonadotropin-releasing hormone neurons genetically targeted with green fluorescent protein. J Neurosci (2002) 22(6):2313-22.

137. Constantin S, Wray S. Galanin activates G-protein gated inwardly rectifying potassium channels and suppresses kisspeptin-10 activation of GnRH neurons. Endocrinology (2016) 157(8):3197-212. doi:10.1210/en. 2016-1064

138. Nunez L, Villalobos C, Boockfor FR, Frawley LS. The relationship between pulsatile secretion and calcium dynamics in single, living gonadotropinreleasing hormone neurons. Endocrinology (2000) 141(6):2012-7. doi:10.1210/ endo.141.6.7491

139. Fuenzalida LC, Keen KL, Terasawa E. Colocalization of FM1-43, Bassoon, and GnRH-1: GnRH-1 release from cell bodies and their neuroprocesses. Endocrinology (2011) 152(11):4310-21. doi:10.1210/en.2011-1416

140. Glanowska KM, Venton BJ, Moenter SM. Fast scan cyclic voltammetry as a novel method for detection of real-time gonadotropin-releasing hormone release in mouse brain slices. J Neurosci (2012) 32(42):14664-9. doi:10.1523/ jneurosci.1303-12.2012

141. Glanowska KM, Moenter SM. Differential regulation of GnRH secretion in the preoptic area (POA) and the median eminence (ME) in male mice. Endocrinology (2015) 156(1):231-41. doi:10.1210/en.2014-1458
142. Christian CA, Mobley JL, Moenter SM. Diurnal and estradiol-dependent changes in gonadotropin-releasing hormone neuron firing activity. Proc Natl Acad Sci U S A (2005) 102(43):15682-7. doi:10.1073/pnas.0504270102

143. Tobin V, Leng G, Ludwig M. The involvement of actin, calcium channels and exocytosis proteins in somato-dendritic oxytocin and vasopressin release. Front Physiol (2012) 3:261. doi:10.3389/fphys.2012.00261

144. Iremonger $\mathrm{KJ}$, Herbison $\mathrm{AE}$. Initiation and propagation of action potentials in gonadotropin-releasing hormone neuron dendrites. JNeurosci (2012) 32(1):151-8. doi:10.1523/jneurosci.3739-11.2012

145. Lee K, Duan W, Sneyd J, Herbison AE. Two slow calcium-activated afterhyperpolarization currents control burst firing dynamics in gonadotropinreleasing hormone neurons. J Neurosci (2010) 30(18):6214-24. doi:10.1523/ JNEUROSCI.6156-09.2010

146. Burgoyne RD, Morgan A. Ca2+ and secretory-vesicle dynamics. Trends Neurosci (1995) 18(4):191-6. doi:10.1016/0166-2236(95)93900-I

147. Burgoyne RD, Morgan A. Secretory granule exocytosis. Physiol Rev (2003) 83(2):581-632. doi:10.1152/physrev.00031.2002

148. Liu X, Lee $\mathrm{K}$, Herbison AE. Kisspeptin excites gonadotropin-releasing hormone neurons through a phospholipase $\mathrm{C} /$ calcium-dependent pathway regulating multiple ion channels. Endocrinology (2008) 149(9):4605-14. doi:10.1210/en.2008-0321

Conflict of Interest Statement: The author declares that the research was conducted in the absence of any commercial or financial relationships that could be construed as a potential conflict of interest.

Copyright (C) 2017 Constantin. This is an open-access article distributed under the terms of the Creative Commons Attribution License (CC BY). The use, distribution or reproduction in other forums is permitted, provided the original author(s) or licensor are credited and that the original publication in this journal is cited, in accordance with accepted academic practice. No use, distribution or reproduction is permitted which does not comply with these terms. 